\title{
Pengaruh Profitabilitas, Likiuditas, Leverage, Ukuran Perusahaan, Dan Kebijakan Dividen Terhadap Nilai Perusahaan (Studi Empiris Pada Perusahaan Consumer Goods Industry yang Terdaftar di Bursa Efek Indonesia 2017-2018)
}

\author{
Dewi purwaningtyas ${ }^{1}$, Dirvi Surya Abbas $^{2}$ \\ Fakultas Ekonomi dan Bisnis Universitas Muhammadiyah Tangerang ${ }^{1,2}$ \\ e-mail: dewipurwaningtyas846@gmail.com (email korespondensi)
}

\begin{abstract}
Abstrak: Penelitian ini bermaksud untuk mengevaluasi pengaruh profitabilitas, likiuditas, leverage, ukuran perusahaan, dan kebijakan dividen terhadp Nilai Perusahaan yang diukur dengan Tobin Q. Populasi dalam penelitian ini adalah seluruh perusahaan Consumer Goods Industry yang Terdaftar di Bursa Efek Indonesia 2017-2018. Kemudian pengambilan sampel menggunakan system purposive sampling dan diperoleh 15 perusahaan. Data yang digunakan adalah data sekunder berupa laporan keuangan tahunan perusahaan yang terdaftar di Bursa Efek Indonesia selama periode 2017-2018. Penelitian ini menggunakan analisis regresi data panel. Hasil kajian menyatakan bahwa Leverage dan ukuran perusahaan berpengaruh terhadap nilai perusahaan, sedangkan profitabilitas, likuiditas, ukuran perusahaan dan Kebijakan Dividen tidak berpengaruh terhadap nilai perusahaan.
\end{abstract}

Kata kunci: Profitabilitas,Likuiditas,Leverage, Ukuran Perusahaan, Kebijakan Dividen, Nilai Perusahaan.

Nilai perusahaan adalah gambaran dari nilai pasar suatu perusahaan dimana dengan nilai pasar saham yang besar berarti saham tersebut akan disukai oleh investor, dengan meningkatnya permohonan saham akan menyebabkan nilai perusahaan akan semakin tinggi (Anggraeni 2015). Industri makanan dan minuman sedang menjadi bidang andalan penunjang pertumbuhan manufaktur di Indonesia. Jakarta, Selasa (23/10/2018). Selama 2014-2018, pemerintah telah meluaskan 13 kawasan industri baru di pulau Jawa dan luar Jawa. Peningkatan juga dilakukan dengan menambah 22 sentra industri rendah dan sedang di 22 kota/kabupaten di luar pulau Jawa. Sumber: (Berita Money Ekonomi Indonesia Terbaru Hari ini - Kompas.com n.d.) Melihat fenomena tersebut, peneliti tertarik untuk melakukan penelitian mengenai kondisi kinerja keuangan Perusahaan Consumer Goods Industry terhadap nilai perusahaan. Salah satu cara ukur yang digunakan investor perlu melihat nilai perusahaan adalah Tobin's $Q$. Semakin besar tingkat rasio Tobin's $Q$ suatu perusahaan maka perusahaan tersebut dikatakan semakin sanggup dan berhasil dalam menciptakan nilai bagi pemegang saham (Hasibuan, Dzulkirom AR, and Wi Endang NP 2016). Diperoleh beberapa aspek yang dapat memastikan nilai perusahaan antara lain Profitabilitas, Likiuditas, Leverage, ukuran perusahaan, dan kebijakan dividen. Dalam pengkajian ini, nilai perusahaan diukur dengan Tobin's Q. Menurut (Hasibuan et al., 2016) Tobin's $Q$ merupakan perbandingan antara nilai pasar ditambah total utang terhadap total aset. Nilai Tobin's $Q$ mengilustrasikan mengilustrasikan suatu keadaan peluang investasi yang dimiliki 
perusahaan atau kemampuan pertumbuhan perusahaan (Tobin \& Brainard, 1969 dalam (Denny Kurnia, 2017). Sehingga tobin's $Q$ dipilih sebagai alat untuk menghitungkan nilai perusahaan. Profitabilitas merupakan keahlian suatu perusahaan dalam menciptakan laba pada periode tertentu. Menurut Sartono (2010) dalam (Widyantari and Yadnya 2017) profitabilitas merupakan kemampuan suatu perusahaan untuk memperoleh laba dalam hubungannya dengan penjualan, total asset, maupun modal sendiri. Profitabilitas dapat ditakar dengan menggunakan Return On Asset (ROA). Rasio ini mengukur daya guna perusahaan dengan keutuhan aset yang digunakan untuk operasi perusahaan dalam menghasilkan profit atau laba. Menurut Menurut (Lubis, Sinaga, and Sasongko 2017) Current ratio dapat memberikan gambaran tentang keahlian suatu perusahaan untuk mencukupi kewajiban - kewajiban jangka pendeknya. Menurut (Denny Kurnia 2017) mendapatkan bahwa rasio leverage merupakan rasio yang membuktikan bagaimana perusahaan mampu untuk mengatur utangnya dalam rangka mendapat margin dan juga mampu untuk membayar kembali utangnya. (Denny Kurnia 2017) juga mengatakan dalam buku terjemahan Horne \& Wachowicz, (2009: 479) dijelaskan bahwa leverage ialah pemakaian biaya tetap untuk menaikan profitabilitas. Ukuran perusahaan adalah skala untuk menentukan besar kecilnya suatu perusahaan terbagi menjadi 3 macam, yaitu perusahaan besar (large firm), perusahaan menengah (medium firm), dan perusahaan kecil (small firm). Keputusan yang dikeluarkan oleh ketua Bapepam No.Kep.11/PM/1997 menyebutkan bahwa perusahaan kecil dan menengah berdasarkan asset adalah badan hukum yang memiliki total aset tidak lebih dari seratus milyar, Menurut (Pratama\& Wiksuana, 2016). Kebijakan dividen bias ditakar dengan Dividend Payout Ratio (DPR). Dimana DPR membandingkan antara dividen per lembar saham dengan laba per lembar saham Dividen merupakan pembayaran dari perusahaan kepada para pemegang saham atas keuntungan yang diperolehnya. Dari perolehan analisis data dan diskusi yang sudah diuraikan pada bab sebelumnya, bahwa penelitian ini dilakukan untuk melihat pengaruh profitabilitas, likuiditas, leverage, ukuran perusahaan, dan kebijakan dividen terhadap nilai perusahaan.

\section{METODE}

Data yang digunakan yaitu sektor Consumer Goods Industry yang terdaftar di Bursa Efek Indonesia (BEl) data laporan keuangan tahunan dalam kurun waktu2017-2018 yang diakses langsung dari situs Bursa Efek Indonesia (BEI) www.idx.co.id. Perusahaan yang terdaftar di Bursa Efek Indonesia (BEI) selama periode 2017- 2018 adalah sebanyak 51 perusahaan. Dalam penelitian ini dipilihnya perusahaan Sektor Consumer Goods Industry karena perusahaan paling banyak mengalami laba operasi negative selama tahun 2016 hingga 2018. Hal ini mengindikasikan suatu

kinerja perusahaan yang kurang baik atau merupakan suatu tahap penurunan kondisi keuangan perusahan sehingga dapat mempengaruhi 
nilai perusahaan. Teknik pengambilan sampel dalam penilitian ini dilakukan dengan menggunakan teknik purpose sampling, yang berarti pemilihan sampel berdasarkan kriteria adalah sebanyak 15 perusahaan selama periode 2017-2018, sehingga jumlah data adalah 15 perusahaan selama periode 2017-2018, sehingga jumlah data adalah 30 data. Penelitian ini menggunakan dua jenis Variabel independen yaitu Profitabilitas, Likuiditas, Leverage, Ukuran Perusahaan, dan Kebijakan Dividen. Metode pengumpulan data yg digunakan penelitian yaitu metode dokumentasi. Metode dokumentasi adalah metode yang digunakan untuk melihat, mendalami dan memakai data-data sekunder yang didapatkan dari situs resmi BEI, seperti data yang dipublikasikan dalam IDX, laporan keuangan dan data lainnya di BEI. Data yang dikumpulkan dari penelitian ini adalah data-data mengenai profitabilitas, likuiditas, leverage, ukuran perusahaan, kebijakan dividen dan nilai perusahaan yang terdapat dalam laporan tahunan pada sektor Consumer Goods Industry di Bursa Efek Indonesia (BEI) selama tahun 2017 - 2018. Dari hasil pemilihan sampel yang terpilih 15 perusahaan yang memenuhi kriteria. Teknik Pemilihan Model Regresi Data Panel terbagi menjadi 3 model yaiut uji chow, uji hausman, dan uji lagrange multiplier.

Tabel 1 Uji Chow

\begin{tabular}{lrrr}
\hline Effects Test & Statistic & d.t & Proo \\
\hline \hline Cross-section F & 0.941520 & $(14,10)$ & 0.5532 \\
Cross-section Chil-square & 25.222794 & 14 & 0.0324 \\
\hline \hline
\end{tabular}

Uji Chow untuk membandingkan antara model common effect dan fixed effect model untuk selanjutnya dipilih sebagai model-model regresi panel yang lebih baik. Chow test pada pengkajian ini menggunakan program Eviews 9.0 (Darmawan \& Lifatin, 2019). Adapun hipotesis yang dibentuk dalam uji chow adalah sebagai berikut : HO: Common effect Model $\mathrm{Ha}$ : Fixed effect model $\mathrm{HO}$ ditolak jika $\mathrm{p}$ - value lebih kecil dari $\alpha=$ 0,05 . Sementara HO diterima jika $p$-value lebih besar dari $\alpha=0,05$. Berdasarkan hasil perhitungan diatas, nilai Probabilitas Cross- section $\mathrm{F}$ $0.5532>$ a $(0,05)$, maka dapat disimpulkan bahwa Common Effect Model (CEM) lebih layak digunakan dibandingkan Fixed Effect Model (FEM).

Tabel 2 Uji Hausman

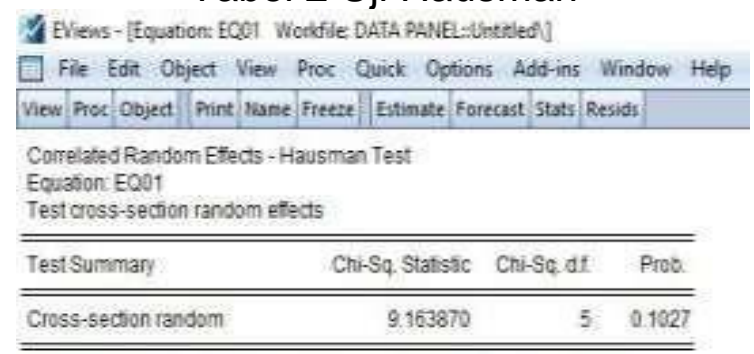

Uji hausman akan membandingkan dan memilih antara fixed effect model dan random effect model untuk menentukan model regresi panel yang terbaik. Hausman test dalam penelitian ini menggunakan program 
eviews 9.0 (Darmawan \& Lifatin, 2019). Adapun hipotesis yang dibentuk dalam uji hausman adalah sebagai berikut : Ho : Random effect model $\mathrm{Ha}$ : Fixed effect model Ho ditolak jika $\mathrm{p}$-value lebih kecil $\alpha=0,05$. Sebaliknya Ho diterima jika $p$ - value lebih besar dari $\alpha=0,05$. Berdasarkan hasil perhitungan diatas, nilai Probabilitas Cross- section random 0.1027 > a $(0,05)$, maka dapat disimpulkan bahwa Random Effect Model (REM) lebih layak digunakan dibandingkan Fixed Effect Model (FEM).

Tabel 3 Uji Lagranga Multiper

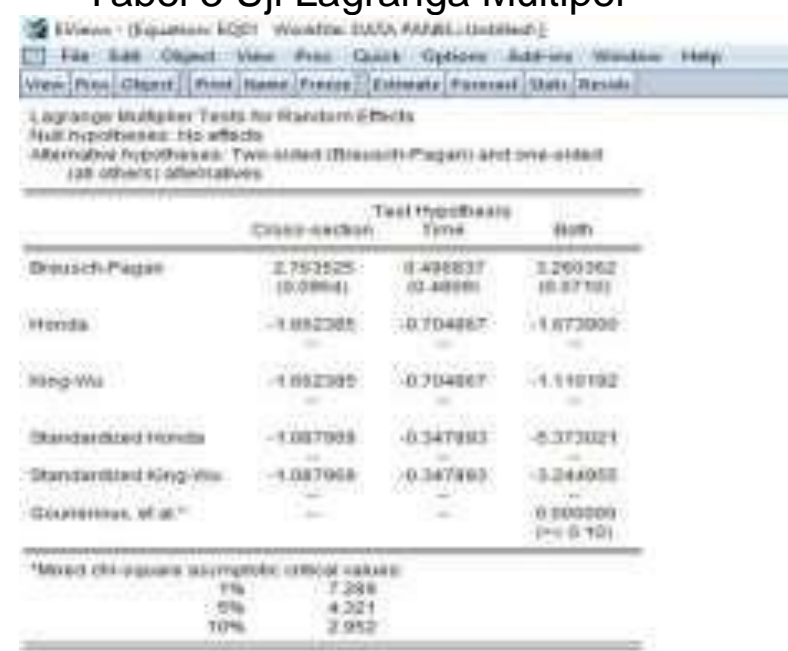

Uji lagranga multiper (LM) digunakan untuk menentukan model data panel yang terpilih antara random effect dan common effect model (Darmawan \& Lifatin, 2019). Mengenai hipotesis yang dibentuk dalam uji lagrange multiper adalah sebagai berikut: $\mathrm{Ho}$ : Common effect model $\mathrm{Ha}$ : Random effect model Ho ditolak jika $p$-value lebih kecil $\alpha=0,05$. Sebaliknya $H_{0}$ diterima jika $p$-value lebih besar dari $\alpha=0,05$. Berdasarkan hasil perhitungan diatas, nilai Probabilitas Cross- section Breausch-pagan $0.0964>$ a $(0,05)$, maka dapat disimpulkan Common Effect Model (CEM) lebih layak digunakan dibandingkan Random Effect Model (REM).

\section{HASIL}

Tabel 4 Kesimpulan Model Regresi Data Panel Yang Digunakan

\begin{tabular}{c|l|c|c|}
\hline No & \multicolumn{1}{|c|}{ Metode } & Pengujian & Hasil \\
\hline 1 & Uji Chow & CEM VS FEM & CEM \\
\hline 2 & Uji Hausman & REM VS FEM & REM \\
\hline 3 & Uji Lagrange Multiplier & CEM VS REM & CEM \\
\hline
\end{tabular}

Berdasarkan hasil ketiga pengujian yang sudah dilakukan maka dapat disimpulkan bahwa model regresi data panel yang akan digunakan dalam uji hipotesis dan persamaan regresi data panel adalah model Common Effect Model (CEM). 
Tabel 5 Uji Multikolinieritas

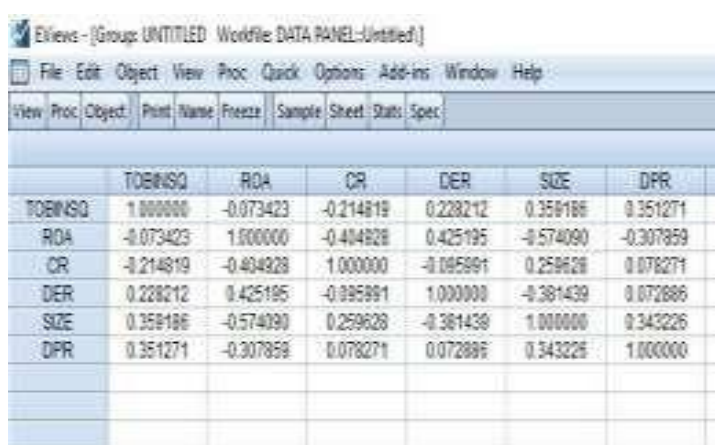

Berdasarkan table diatas, dapat dilihat tidak terdapat variable indenpenden yang memiliki nilai lebih dari 0,8 sehingga dapat disimpulkan tidak terjadi multikolinieritas dalam model regresi.

Tabel 6 Uji Heteroskedastisitas

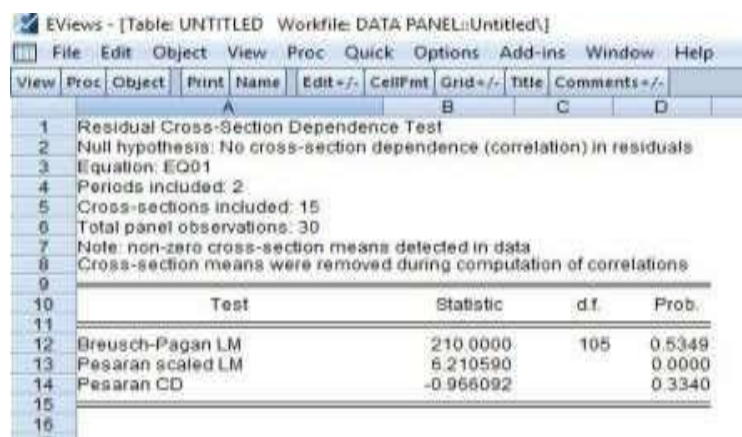

Berdasarkan table diatas, dapat dilihat nilai Breusch-Pagan LM sebesar $0.5349>\alpha(0,05)$, maka HO diterima yang artinya tidak terjadi Heteroskedastisitas pada model regresi data panel.

Tabel 7 Uji Kelayakan Model (F)

Berdasarkan hasil tabel Fixed Effect Model yang ditampilkan pada

\begin{tabular}{|c|c|c|c|}
\hline R-squared & 0.410637 & Mean dependentvar & 1.328090 \\
\hline Adjusted R-squared & 0.287852 & S.D. dependentvar & 0.936242 \\
\hline S.E. of regression & 0.790084 & Akaike info citterion & 2.543502 \\
\hline Sum squared resid & 14.98159 & Schwarz criterion & 2823741 \\
\hline Loglikelihood & .3215253 & Hannan-Quinn criter. & 2.833153 \\
\hline F-statistic & 3.344380 & Durbin-Watson stat & 2.679799 \\
\hline propif-statistictiof & 0040572 & & \\
\hline
\end{tabular}

tabel diatas menunjukan bahwa nilai $F$ - statistic sebesar 3,344380, sementara $F$ tabel dengan tingkat $5 \%$, df1 $(\mathrm{k}-1)=5$ dan df2 $(\mathrm{n}-\mathrm{k})=24$ didapat nilai $F$ Tabel sebesar 3,40. Dengan demikian $F$-statistic $(3,344380)<F$ tabel $(3,40)$ dan nilai prob F- statistic) $0,019672<0,05$ maka dapat disimpulkan bahwa $\mathrm{Ha}$ diterima, maka dengan demikian dapat disimpulkan bahwa variable - variabel independen dalam penelitian 
ini yang terdiri dari ROA, CR, DER, SIZE dan DPR secara bersama-sama memiliki pengaruh terhadap Nilai Perusahaan.

Tabel 8 Uji R2(Koefisien Determinasi)

\begin{tabular}{|c|c|c|c|}
\hline $\begin{array}{l}\text { R-squared } \\
\text { Adjusted R-squared }\end{array}$ & $\begin{array}{l}0.410637 \\
0.287852 \\
\end{array}$ & $\begin{array}{l}\text { Mean dependentvar } \\
\text { S.D. dependentvar } \\
\text { Akaike into citerion }\end{array}$ & $\begin{array}{l}1.328090 \\
0.936242 \\
2542502\end{array}$ \\
\hline Sum squared resid & 14.98159 & Schwar criterion & 2.823741 \\
\hline Log likelihood & -32.15253 & Hannan-Quinn criter. & 2.833153 \\
\hline F-statistic & 3.344380 & Durbin-Watson stat & 2.679799 \\
\hline Prob(F-slatistic) & 0.019672 & & \\
\hline
\end{tabular}

Pada tabel diatas menunjukkan bahwa nilai Adjusted R-squared sebesar 0,287852, artinya bahwa variasi perubahan naik turunnya Nilai Perusahaan dapat dijelaskan oleh ROA, CR, DER, SIZE dan DPR sebesar 28,78 persen, sejumlah sisanya yaitu sebesar 71,22 persen dijelaskan oleh variabel-variabel lain yang tidak diteliti dalam penelitian ini.

Tabel 9 Ringkasan Pengujian Hipotesis

\begin{tabular}{|c|c|c|c|c|}
\hline Varobin & Coefoer & $9 \pi$ ero & istatsto & Pya \\
\hline c & -1360191 & 6) วеаเ & tatesos & actor \\
\hline FOA & Asero: & Orgese & 9.121001 & 094at \\
\hline$a$ & 021454 & 0.50046 & -154505 & $0053=$ \\
\hline bea & 057300 & 028736 & $t 14114 t$ & 00426 \\
\hline int & 0.97451 & 0. รูงดาง & 210154 & 0016 \\
\hline DAR & 0800033 & 0.0097 & 2300538 & 11376 \\
\hline
\end{tabular}

Dari hasil yang ditampilkan pada tabel diatas menunjukan bahwa hasil uji t variabel Profitabilitas (ROA), Likuiditas (CR), Leverage (DER), Ukuran Perusahaan (SIZE), dan Kebijakan Dividen ( DPR ) terhadap Nilai Perusahaan adalah sebagai berikut : Nilai t-statistic Profitabilitas (ROA) sebesar $-0,121023$, sementara $t$ Tabel dengan tingkat $\alpha=5 \%$, df $(n-k)=$ 24 didapat nilai t Tabel sebesar 2,06390. Dengan demikian t-statistic ROA $<$ t Tabel $(2,06390)$ dan nilai Prob. 0,9047 > 0,05 maka dapat disimpulkan bahwa variabel Profitabilitas (ROA) dalam penelitian ini tidak memiliki pengaruh terhadap pengungkapan Nilai Perusahaan. Dengan demikian, $\mathrm{H} 1$ dalam penilitian ini ditolak. Nilai $t$-statistic Likuiditas (CR) sebesar -1.946105, sementara t Tabel dengan tingkat $\alpha=5 \%$, df $(n-k)=24$ didapat nilai $\mathrm{t}$ Tabel sebesar 2,06390. Dengan demikian t-statistic Likuiditas $<\mathrm{t}$ Tabel (2,06390) dan nilai Prob. 0,0634 > 0,05 maka dapat disimpulkan bahwa variabel Likuiditas (CR) dalam penelitian ini tidak memiliki pengaruh terhadap pengungkapan Nilai Perusahaan Dengan demikian, $\mathrm{H} 1$ dalam penilitian ini ditolak. Nilai t-statistic Leverage (DER) sebesar 2,141149 , sementara $t$ Tabel dengan tingkat $\alpha=5 \%$, df $(n-k)=24$ didapat nilai $t$ Tabel sebesar 2,06390. Dengan demikian t-statistic Leverage $>t$ Tabel $(2,06390)$ dan nilai Prob. 0,0426 < 0.05 maka dapat disimpulkan bahwa variabel Leverage (DER) dalam penelitian ini memiliki pengaruh positif terhadap Nilai Perusahaan. Dengan demikian, $\mathrm{H} 1$ dalam penelitian 
ini diterima. Nilai $t$-statistic Ukuran Perusahaan (SIZE) sebesar 2,603975, sementara $\mathrm{t}$ Tabel dengan tingkat $\alpha=5 \%$, df $(n-k)=24$ didapat nilai $t$ Tabel sebesar 2,06390. Dengan demikian t-statistic Ukuran Perusahaan $>\mathrm{t}$ Tabel (2,06390) dan nilai Prob. 0,0156 < 0.05 maka dapat disimpulkan bahwaUkuran Perusahaan (SIZE) dalam penelitian ini memiliki pengaruh positif terhadap Nilai Perusahaan. Dengan demikian, $\mathrm{H} 1$ dalam penelitian ini diterima. Nilai $t$-statistic Kebijakan Dividen (DPR) sebesar 0,900536, sementara t Tabel dengan tingkat $\alpha=5 \%$, df $(n-k)=24$ didapat nilai t Tabel sebesar 2,06390. Dengan demikian t-statistic Kebijakan Dividen < t Tabel $(2,06390)$ dan nilai Prob. 0,3768 > 0,05 maka dapat disimpulkan bahwa variabel Kebijakan Dividen (DPR) dalam penelitian ini tidak memiliki pengaruh terhadap pengungkapan Nilai Perusahaan. Dengan demikian, $\mathrm{H} 1$ dalam penilitian ini ditolak. 


\section{SIMPULAN DAN SARAN}

Dari perolehan analisis data dan diskusi yang sudah diuraikan pada bab sebelumnya, bahwa penelitian ini dilakukan untuk melihat pengaruh profitabilitas, likuiditas, leverage, ukuran perusahaan, dan kebijakan dividen terhadap nilai perusahaan. Jadi bisa diambil pendapat dari hasil analisis regresi berganda sebagai berikut: Profitabilitas tidak berpengaruh terhadap nilai perusahaan, yang ditunjukkan dengan nilai signifikansi profitabilitas terhadap nilai perusahaan diatas 0,05 yaitu sebesar 0,9047 . Likuiditas tidak berpengaruh terhadap nilai perusahaan, yang ditunjukkan dengan nilai signifikansi likuiditas terhadap nilai perusahaan diatas 0,05 yaitu sebesar 0,0634. Leverage berpengaruh terhadap nilai perusahaan, yang ditunjukkan dengan nilai signifikansi leverage terhadap nilai perusahaan dibawah 0,05 yaitu sebesar 0,0426. Ukuran Perusahaan berpengaruh terhadap nilai perusahaan, yang ditunjukkan dengan nilai signifikansi ukuran perusahaan terhadap nilai perusahaan dibawah 0,05 yaitu sebesar 0,0156. Kebijakan Dividen tidak berpengaruh terhadap nilai perusahaan, yang ditunjukkan dengan nilai signifikansi Kebijakan Dividen terhadap nilai perusahaan diatas 0,05 yaitu sebesar 0,3768. Bersumber keterbatasan yang diungkapkan, jadi peneliti memberikan saran sebagai berikut: Peneliti berikutnya disarankan menggunakan sampel dari sektor lain untuk diteliti serta memperpanjang periode observasi agar mendapatkan jumlah sampel yang lebih baik. Penelitian ini menggunakan lima variabel independen untuk menilai faktor-faktor yang dapat mempengaruhi nilai perusahaan. Jadi, peneliti yang akan dapat menambahkan variabel baru, dan menghubungkannya untuk mengetahui faktor-faktor lain yang dapat mempengaruhi nilai perusahaan. Bagi perusahaan CGI, hendaknya untuk meningkatkan profitabilitas dan lebih memperhatikan tingkat aset lancar yang dimiliki yang dapat mempengaruhi likuiditas perusahaan. Karena sebagian investor selain melihat tingkat keuntungan juga melihat tingkat likuiditas perusahaan.

\section{DAFTAR PUSTAKA}

Anggraeni, I Gusti Made Andrie Kayobi Desy. 2015. "PENGARUH DEBT TO EQUITY RATIO(DER), DEBT TO TOTAL ASSET(DTA), DIVIDEN TUNAI, DAN UKURAN PERUSAHAAN TERHADAP NILAI PERUSAHAAN (Perusahaan Manufaktur Sektor Barang Konsumsi Yang Terdaftar Di Bursa Efek Indonesia Periode 20112014)." Jurnal Akuntansi dan Keuangan 4(1): 100-120.

"Berita Money Ekonomi Indonesia Terbaru Hari Ini - Kompas.Com." https://ekonomi.kompas.com/ (July 15, 2020).

Denny Kurnia. 2017. "Analisis Signifikansi Leverage Dan Kebijakan Deviden Terhadap Nilai Perusahaan." Journal of Accounting 4(2): 12-21.

Eka Indriyani. 2017. "Pengaruh Ukuran Perusahaan Dan Profitabilitas

Terhadap Nilai Perusahaan." Jurnal IImu Akuntansi 10(2): 333-48.

Hardian, Ananda Putra, and Nur Fadjrih Asyik. 2016. "Kinerja Keuangan 
Dan Ukuran Perusahaan Terhadap Nilai Perusahaan, CSR Sebagai Variabel Moderasi." : 2460-0585.

Prof. Dr. Sugiyono. 2015. Statistik Untuk Penelitian. ed. M. Pd Endang Mulyatiningsih. Bandung: CV ALFABETA.

Putra, AA Ngurah Dharma Adi, and Putu Vivi Lestari. 2016. "PENGARUH KEBIJAKAN DIVIDEN, LIKUIDITAS, PROFITABILITAS DAN UKURAN PERUSAHAAN TERHADAP NILAI PERUSAHAAN." EJurnal Manajemen Universitas Udayana 5(7): 2302-8912.

Putra, I Putu Mega Juli Semara, and Ni Made Rai Juniariani. 2017. "ANALISIS RASIO KEUANGAN TERHADAP NILAI PERUSAHAAN DI BURSA EFEK INDONESIA." Jurnal Akuntansi 1: 143-50.

Putri, Rachmalia, and Maria Wi Endang NP. 2016. "PENGARUH RASIO LIKUIDITAS DAN RASIO PROFITABILITAS TERHADAP NILAI PERUSAHAAN (Studi Pada Perusahaan Sektor Industri Barang 